\title{
BOOKS PREFERRED BY ABORIGINAL CHILDREN
}

\author{
*W. Langlands, G. Evans \\ and R. Marsh
}

\section{INTRODUCTION}

From October to December 1982 a small scale informal study was conducted to discover what books were preferred by Aboriginal children at the Jigalong Special Aboriginal School, in the Pilbara region of Western Australia. Two teachers and their classes were involved in the study.

A representative selection of 250 books was taken from the Jigalong school library. This library contains books selected by teachers and others with a view to their being suitable for Jigalong's $100 \%$ Aboriginal school population. The selected books were numbered, lists made and a recording slip like that pictured below (Figure 1) was fixed in the back of each book.

\section{Figure 1}

\begin{tabular}{|l|}
\hline Week 1 \\
\hline Week 2 \\
\hline Week 3 \\
\hline Week 4 \\
\hline Week 5 \\
\hline
\end{tabular}

Teachers then timetabled periods of approximately thirty minutes each day for the few weeks that the book selection was in their room. During these periods the selected books replaced other reading material in the classroom as the class library. Children were expected to select books, read them and mark the recording slip at the back with a tick when they returned the book to the shelf. There was some

* Mr William Langlands, Summer Institute of Linguistics literacy specialist, Jigalong, W.A.

Mr Garry Evans, Teacher, Jigalong Special Aboriginal Schoal

Ms Rosalie Marsh, formerly teacher, Jigalong Special Aboriginal School. 
evidence that recording was not done with complete accuracy despite frequent reminders from the class teachers. The original intention was to use the boxes labelled Week 1 etc., to discover if there was any change in preference for books during the course of the study. This proved to be too difficult, however, and was abandoned in favour of an overall total of times that each book had been read.

\section{RESULTS}

Class 1 was a group of upper primary and post primary girls. The average attendance during the study was 10.5 girls. This class read the books for 20 reading periods with the following results.

\begin{tabular}{lcc} 
No. $\frac{\text { Table } 1}{\text { of times }}-\frac{\text { Class } 1,10.5}{1}$ students, 20 reading periods, 248 books \\
books read & $\begin{array}{c}\text { No of books } \\
\text { read }\end{array}$ & $\begin{array}{c}\% \\
\text { of total books }\end{array}$ \\
$13-18$ & 3 & 1.2 \\
$8-9$ & 7 & 2.8 \\
$6-7$ & 14 & 5.7 \\
$4-5$ & 31 & 12.5 \\
3 & 35 & 16.1 \\
2 & 42 & 21.4 \\
1 & 53 & 25.4 \\
\hline
\end{tabular}

It should be noted that two books were mislaid during the study, so only 248 books were finally scored for this group.

On1y three $(1.2 \%)$ of the books were read 13 or more times. This means that only these three books could have been read once or more by every member of the class. $63.7 \%$ of the books (158) were read only twice or less during the twenty reading periods. $25.4 \%$ (63 books) were not read at all.

A list of the books that were possibly read by half the class, or more, at least once during the time of the study is given in Table 2. The books are in order of preference. These are the top 24 books, $9.7 \%$ of the total.

Class 2 was a group of middle primary girls and boys. The average attendance during the weeks when the class had the 29 reading sessions was 20 . Table 3 shows the tallies they recorded for the 247 books that were used throughout the reading sessions. Three of the original selection were mislaid and therefore not included in the tallies. 45 books, $18.2 \%$ of the total could have been read once or 
Table 2 - Top Book Preferences for Class 1

Total

Readings

Title, Author, Publisher/Series

18

Molok the Thirsty Frog, L. \& G. Adams, S.R.A.

14 Australian Dreaming, J. Isaacs, Landsdowne Press

13 Bears in the Night, S. \& J. Berenstein, Collins, Beginner

9 A Fish Out of Water, H. Palmer, Collins, Beginner The Oath of Bad Bill Brown, S. Axelsen, Nelson Are You My Mother? P.E. Eastman, Collins, Beginner The Koala Who Stole Water, L. \& G. Adams, S.R.A. National Geographic Vol.160, No.3, National Geographic How the Echidna Got His Quilzs, L. \& G. Adams, S.R.A. The Giant Devil Dingo, D. Roughsey, Collins, Picture Lions 7 Baby, D. McMillan, Methuen Educational, PM Instant Reader

6 No School Today, F. Brandenberg, Scholastic Book Ten Apples Up on Top, T. Le Sieg, Collins, Beginner The Three Bears, Little Golden Book, Golden Press Maybe You Should Fly a Jet, T. Le Sieg, Collins, Beginner Three Little Pigs, L. Kincaid, Bimax Books Oh Look at This, D. McMillan, Methuen, Educ. PM Inst.Reader Animals at the Zoo, ditto ditto Round the House, ditto ditto Anna and Dula, R. Vavra, Collins Trouble in the Ark, G. Rose, Puffin Books, Kestre1 The Tale of the Wombat, L. \& G. Adams, S.R.A. Jennifer and Josephine, B. Peet, Andre Deutsch The Chicken Book, G. Williams, Unknown

Table 3 - Class 2, 20 students, 29 reading periods, 247 books

\begin{tabular}{ccc}
$\begin{array}{l}\text { No. of times } \\
\text { books read }\end{array}$ & $\begin{array}{c}\text { No. of books } \\
\text { read }\end{array}$ & $\begin{array}{c}\% \text { of total } \\
\text { books }\end{array}$ \\
\hline 63 & 1 & .4 \\
$26-30$ & 2 & .8 \\
$21-25$ & 8 & 3.2 \\
$16-20$ & 20 & 8.1 \\
$11-15$ & 22 & 8.9 \\
$8-10$ & 11 & 4.5 \\
$6-7$ & 18 & 7.3 \\
$4-5$ & 33 & 13.3 \\
3 & 26 & 10.5 \\
2 & 25 & 10.2 \\
1 & 32 & 13 \\
0 & 22 & 8.9 \\
& 27 & 10.9
\end{tabular}


more by every member of the class. Over $50 \%$ of the books were read only five times or less by this group during the study. Below is a list of the 64 books (25.9\%) that were read ten or more times.

Table 4 - Top Book Preferences for Class 2

Total

Readings

Title, Author, Publisher/Series

63 Asterix and the Chieftain's Shield, Goscinny and Underzo Hodder and Stoughton

30 Look Down, E. \& L. Kincaid, Brimax Books

26 Beouty and the Beast, M. Mayer, Four Winds Press

25 Motor Cycles, R. Kerrod, Franklin Watts

24 Baby Animals, A. Kershaw, Octopus Books 101 Dalmatians, Walt Disney, Walt Disney Product Crazy Cowboy, G. Mordillo, Hutchinson

22 How Can You Hide an Elephant? P.Miles Martin, Longman Cheshire Speed and Power Land, J. Fletcher, Hamish Hamilton Giants, C. Rawson, Usborne/Ashton Sch.

21 Animal Riddles, B. Cerf, Collins, Beginner

20 Put Me in the Zoo, R. Lopshire, Collins, Beginner The Christmas Book, MacDonald Educ., MacDonald Jennifer and Josephine, B. Peet, Andre Deutsch The Wolf and the Seven Little Kids, Grimm, Pelham

19 Ompa-pa and Brother Two Scalp, Goscinny and Uderzo, Egmont \& Methuen

The Giant Devil Dingo, D. Roughsey, Collins, Picture Lions

18 Come and Have Fun, E.T. Hurd, World's Work, I Can Read Book Banana Bird and the Snake Men, T. Trezise and D. Roughsey, Collins

The Fisherman's Son, M. Ginsburg, Julia MacRae Books

The Tale of the Wombat, L. \& G. Adams, S.R.A. Playtime, My Pet Series, Peter Haddock

17 What Made Tiddalik Laugh? J. Troughton, Ne1son The Bear Detectives, S. \& J. Berenstein, Collins Australian Parrots in Colour, L. Robinson, Rigby

16 Old Man Fire, L. \& G. Adams, S.R.A. Treasure Island, Octopus Pop-up, Octopus Books Little Bear, E. H. Minarik, World's Work, I Can Read Book Motor Cycling, G. Forsdyke, Octopus Books The Bunny tho Lost His Tail, P. O'Harris, Golden Press How Echidna Got His Quilzs, L. \& G. Adams, S.R.A.

15 Molok the Thirsty Frog, L. \& G. Adams, S.R.A. Cars, P. Drackett, Octopus Books

The Elves and the Shoemaker, F. Littledale, Scholastic Book Services 
14 Nothing Much Happened Today, M. B. Christian, Addison-Wesley The Ugly Duckling, Walt Disney, Walt Disney Product Kwork Kwork, A.N.U. Press

Farm Animals, R. Burton, Octopus Books

13 Australia, the Land and Its People, MacDonald Educ. MacDonald Long Ago in Bethlehem, M. Kasuya, Adam \& Charles Black Working With Horses, N. McCracken, Woman's Movement, Sugar and Snails

The Big Green Bean, M. Weisbauer, Longman Cheshire, Reading 360 Track Is For Me, L. A. Dickmeyer, Lerner Publications

12 The Koala Who Stole the Water, L. \& G. Adams, S.R.A. Dumbo, Walt Disney, Walt Disney Product

Monster Mania, E. Radlauer, Children's Press

National Geographic, Vo1.158, No.6, National Geographic

11 The Bunyip on Little Mountain, G. O'Donne11, Hodder \& Stoughton MiZibi, T. Gordon and J.B. Haviland, A.N.U. Press

National Geographic, Vo1.159, No.5, National Geographic

The North American Indian, M.R. Gibson, Theorem Publishing and Sampson Low

Lachlan's Walk, L. Hathorn, Methuen

Where Are the Spears, N.T. Dept of Education, N.T. Dept of Education, Tracks

10 The Playful Dolphins, L. McCarter Bridge, National Geographic Young Explorers

Mickey Mouse Brave Little Tailor, Golden Book, Golden Press The Secret of the Cockatoo, L. \& G. Adams, S.R.A.

The Life of Birds, MacDonald Introduction to Nature, MacDonald, Easy to Read

Asterix and the GLadiator, Goscinny and Uderzo, Hodder and Stoughton

Ompa-pa and the Secret Mission, Goscinny and Uderzo, Egmont and Methuen

How Big is Big? H. \& N. Schneider, Brockhampton Press, Picture Science

Grimms Fairy Tales, J. Curruth, Octopus Books

The Easter Egg Artists, A. Adams, Charles Scribner's Sons Bemard the Brolga That Couldn't Dance, D. Burt and T. Bishop, Rigby, Opal Books

The Snake and the Lizard, Isobel Weir, A.H. \& A.W. Reed

In addition to the above information, teachers made notes during the reading periods. The following are significant:

1. More able students tended to select books that were simple enough for them to read. The teacher in Class 1 observed that her students were reading rather than just skimming 
through books. She felt this was due to the fact that books simple enough for the students to read were included in the selection. The previous books she had made available were of the right interest level for the children in her group but not simple enough to be read by the majority of the group.

2. There was co-operation in reading. Children discussed books page by page and picture by picture. More able readers helped others with words or read the books so others could listen. Teachers were asked to help with words.

3. Children return to books that they have enjoyed before, especially those that have been read to them by teachers.

4. Before the books were removed from the classrooms, both classes had several days in which there was a large quantity of comics made available during the reading sessions. These were additional reading periods to those already accounted for in the above figures. Teachers noted that, when comics were introduced to the classes, virtually no reading of books went on at a11.

5. It seems that simple, easy to read books often scored well. Observaton showed, however, that they were seldom read more than once by any one student.

\section{DISCUSSION}

An attempt to classify the books from Tables 2 and 4 according to the content resulted in the following:-

\begin{tabular}{|c|c|c|}
\hline Classification & $\begin{array}{l}\text { No. of } \\
\text { Books }\end{array}$ & Comments \\
\hline Aboriginal legends & 12 & $\begin{array}{l}\text { Mainly the large, colourful S.R.A. } \\
\text { series. }\end{array}$ \\
\hline $\begin{array}{l}\text { Fairy tales and trad- } \\
\text { itional European } \\
\text { stories }\end{array}$ & 10 & $\begin{array}{l}\text { Most with large, colourful illust- } \\
\text { rations. Most with stories well } \\
\text { known to the children. }\end{array}$ \\
\hline Various stories & 12 & $\begin{array}{l}\text { All attractive, good, children's } \\
\text { stories. Most with interesting, } \\
\text { unusual, colourful, or humorous } \\
\text { illustrations, or photos, or a } \\
\text { combination of these factors. }\end{array}$ \\
\hline
\end{tabular}


Beginner Book Series

Books about animals

and birds

Comic-1ike books

Books about cars and motorbikes

PM Instant Readers

National Geographic

Walt Disney

Natural Science Books

Indians

Visual Puzzle

Other books
8 Most with a humorous or attractive story. Al1 with good illustrations. The Animal Riddle book largely incomprehensible from a language point of view but probably enjoyed for its humorous and unusual drawings.

7 The text of these, with two exceptions, is too hard. However, the large colour photos and drawings are attractive.

5 Includes Asterix, Ompa-pa and Crazy Cowboy. The latter has no text at all.

4 All large attractive books. Not all preferred by the all girls class.

4 These were preferred by the girls from Class 1. The topics are definitely domestic and the simple texts were read, not just looked at.

3 These magazines deal with other interesting cultures and have a multitude of good colour photos. The text is seldom read.

4 Simple, interesting stories with characters already known from film, comics and records.

2 Both these books have unusual, interesting illustrations. The text in the How $B i g$ Is Big book is too difficult unless read by the teacher.

1 Familiar in "Westerns". A very interesting culture. Illustrations are good but the text is too difficult.

1 The children enjoyed trying to find the spear. Other books in this series (Tracks) were not preferred.

8 Some of these books were of topical interest, e.g. a book on Christmas and a book on athletics. At the time of the study both these topics were of current interest to the children. A book on horses was of interest as it is part of the Jigalong cattle station environment.

Pop-up books and monster books seem generally attractive to these children. Another book, Australia, the Land and Its People contained a lot of pictures of Aboriginal people and familiar scenes, as did the book on the Dreaming. Both these books were looked at rather than read. The text was too difficult. 
It is very difficult to say what factors make a book a "good one" just by looking at a selection of books. We trust that some of the comments above give ideas.

\section{CONCLUSIONS}

Many of the books available in the school library may not be attractive to Aboriginal children. Most of the books that were preferred were books with good stories and especially those with stories that were familiar in some way. Preferred books also often had interesting, humorous, colourful, or unusual illustrations or photos. Books that homed in on current or local interests or were about Aboriginal or similar cultures, also were of interest. However, some books about Papua New Guinea cultures were hardly touched. Dreamtime and fairy stores were very popular.

Comics are very attractive. Their use in the class eclipsed the use of books almost entirely. We wonder, however, how much of the text is actually read.

Books with difficult text are looked at only if they are attractive for some other reason. The ideal combination, which encouraged reading rather than just looking and discussion, seemed to be a simple text along with good illustrations and stories or topics that contain the elements of humour and/or interest and/or familiarity.

Boys and girls, as one would expect, do differ in their tastes. Boys like cars, motor bikes, etc., while girls are interested in domestic topics like babies, houses and so forth. However, there do seem to be areas of common interest.

If teachers want to have books read, then they should, it seems, choose books according to the criteria suggested above and spend a lot of time reading them to children. This will arouse interest and give unsure readers a starting point when they go to the library shelf.

Books with simple, readable texts are essential if there is going to be reading and not just looking. However, much larger numbers of these books would need to be made available. 